\title{
THE NATIONAL ASPECT OF MUSICAL EDUCATION DEVELOPMENT IN UKRAINE AT THE TURN OF THE $21^{\text {st }}$ CENTURY
}

\section{Marta Kliuchynska ${ }^{1}$}

DOI: https://doi.org/10.30525/978-9934-26-050-6-45

Historical events, social, political, and economical changes influence the national cultures. The important part of the culture is arts, among all the musical art. The purpose of this article is to describe the national tendency of musical education development since 1990s till nowadays.

Music contains the national memory of the past, expresses the present social worries, and to the some point predicts the future. A genotype of the nation is preserved through folk music and native composers' works. The difference between various cultures, their uniqueness is mirrored in music. Furthermore, the perception of the world by individual or even whole society is also formed by music.

The various kinds of musical activity are kept in rituals, traditions, and customs that are translated to younger generations by the means of communication and language. Like letters form words, the musical sounds form motives, phrases and sentences, absorbing which a person attains the feeling of belonging to certain culture by learning, embracing and emotionally empathising with music. It stands to reason that each nation has its own musical language, that is, modal melodic and rhythmic relations. The famous saying 'a song is a soul of the nation' the most aptly expresses a spiritual side of Ukrainian culture and the importance of music in our national identification. Many of the Ukrainian artists and public figures pointed out the value of Ukrainian song as a main part of the school process of education. For example, K. Stetsenko said that «the songs of our people are ours history and ours pride. And on them we should resurrect the national spirit of our people, the national self-knowledge» [2, p. 5]. Such statement expressed in $19^{\text {th }}$ century gains even bigger importance nowadays.

The musical education is an important part of the culture, an invaluable achievement of society. The musical education as was defined by V. Shulgina is «a process and result of adoption of the system of musical knowledge and skills, a way to form an aesthetic worldview, and humanistic features of the personality, and means of evolvement of musical capacities and creative potential of the individual» [3, p. 108].

\footnotetext{
${ }^{1}$ Ivan Franko National University of Lviv, Ukraine
} 
The musical education provides the continuation of musical theoretical and practical knowledge moreover it nurtures the personal integrity on national musical traditions, and values. The aim of music first of all is a formation and education of an individual and consequently the society on the attribution of classical Ukrainian compositions, folk songs and modern works.

In the 1991 Ukraine was proclaimed as an independent country. This event instigated the understanding of the necessity of future development of national culture by usage of the tradition of folk pedagogics, and patriotic education. The aim of national school is cultivation of loyalty and love to native culture. The reviving force of national ideas of education is formed by unity of state educational institutions around the idea of achieving the higher patriotic aim. So, the national base of musical education facilitates the solidarity of the society, and functions as device for accumulating, keeping and translating the cultural values to the next generations.

The beginning of the $21^{\text {st }}$ century is characterised by some degree of devaluation of artistic and cultural values, especially among the youth. The oblivion to high musical standards is spreading nowadays, as well as overestimation of the entertaining role of musical art. The classical, folk and sacred music is losing its popularity and might end up completely behind the public attention. These circumstances encourage us to re-evaluate the importance of historical, cultural and national achievements, and crucial role of musical teachers in enriching the inner part of students' personality. Unfortunately, in contrary to folk and academic music, the industry of entertainment is thriving with its lightness and doubtful aesthetic values [1, p. 191].

The accumulation and translation of the national cultural achievements, which is executed by educational institution, including musical education, contributes to the development of the independent nation and opens up new musical and educational horizons.

\section{References:}

1. Mashhenko A. I. (2015) Muzychno-estetychna kompetentnistj pidlitkiv i dukhovna muzyka [Musically-aethetic capacity of adolescents and the sacred music]. Estetyka i etyka pedaghoghichnoji diji, vol. 10, pp. 188-196.

2. Stecenko K. (1917) Ukrajinsjka pisnja v narodnij shkoli: Doklad na zjizdi vchyteliv narodnykh shkil Jampiljsjkogho povitu na Podillju 25.04.1917 r. [Ukrainian song in folk school: the report on teachers gathering of Jampil county]. Vinnycja, 8 p. (in Ukrainian)

3. Shuljghina V. D. (2008) Ukrajinsjka muzychna pedaghoghika (2 vydannja) [Ukrainian musical pedagogics (the second edition)]. Kyiv: DAKKKiM, 263 p. (in Ukrainian) 